\title{
BISPHOSPHONATES IN DENTISTRY - STATE OF THE ART
}

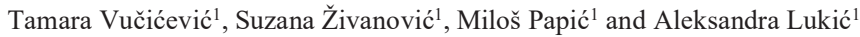

${ }^{I}$ University of Kragujevac, Faculty of Medical Sciences, Department of Dentistry, Serbia

\author{
BISFOSFONATI U STOMATOLOGIJI - PREGLED STANJA U OBLASTI \\ ISTRAŽIVANJA \\ Tamara Vučićević ${ }^{1}$, Suzana Živanović ${ }^{1}$, Miloš Papić1 i Aleksandra Lukić ${ }^{1}$ \\ ${ }^{I}$ Univerzitet u Kragujevcu, Fakultet medicinskih nauka, Katedra za stomatologiju, Srbija
}

\begin{abstract}
Bisphosphonates remain the most used and most effective drugs for the treatment of systemic bone diseases followed by bone resorption. Although their side effects in a form of alveolar bone osteonecrosis have been reported, bisphosphonates have a potential of being used in the treatment of the most common oral diseases followed by alveolar bone resorption such as peri-implantitis, periapical lesions, and periodontitis. The aim of this article was to review the most recent research regarding the use of bisphosphonates in the field of dentistry. The results of studies indicate that bisphosphonate use in the treatment of peri-implantitis, periapical lesions, and periodontitis can reduce alveolar bone resorption and contribute to bone preservation. However, the most beneficial way of their application in the treatment of these oral diseases remain to be determined.
\end{abstract}

Keywords: bisphosphonates, periapical lesions, periimplantitis, periodontitis.

\section{SAŽETAK}

Bisfosfonati su i dalje najviše korišćeni i najefikasniji lekovi u terapiji sistemskih koštanih oboljenja praćenih resorpcijom kostiju. Iako je zabeležen njihov neželjeni efekat u obliku osteoonekroze alveolarne kosti, mnogi veruju da bisfosfonati poseduju potencijal za upotrebu u lečenju najčešćih oralnih oboljenja praćenih resorpcijom alveolarne kosti, poput periimplantitisa, periapikalnih lezija i parodontitisa. Cilj ovog članka bio je pregled najnovijih istraživanja upotrebe bisfosfonata $u$ oblasti stomatologije. Rezultati ispitivanja pokazuju da upotreba bisfosfonata u lečenju peri-implantitisa, periapikalnih lezija $i$ parodontitisa može smanjiti resorpciju alveolarne kosti $i$ doprineti njenom očuvanju. Međutim, ostaje da se odredi najoptimalniji način njihove primene u lečenju ovih oralnih bolesti.

Ključne reči: bisfosfonati, periapikalne lezije, periimplantitis, parodontitis. 


\section{INTRODUCTION}

Bisphosphonates have been widely used in the treatment of systemic bone diseases including bone resorption such as osteoporosis, osteopenia, malignant hypercalcemia, Paget's disease, and bone metastases $(1,2)$. Their therapeutic effect is the reduction of bone loss through inhibition of osteoclasts, which are crucial for bone resorption. (3). Bisphosphonates are analogs of pyrophosphates, a compound found in nature, and their first generation was synthesized by replacing the oxygen molecule by carbon, making them resistant to the bone's hydrolases, and capable of deposing into the bones (Figure 1.;(4)). Consequently, bisphosphonates have a short half-life in circulation, from 30 minutes to 2 hours, and a long half-life in bones, where they could stay deposited up to 10 years following their administration (5).

Figure 1. Modification of the chemical structure of pyrophosphate by replacing oxygen molecules in the process of bisphosphonate synthesis.

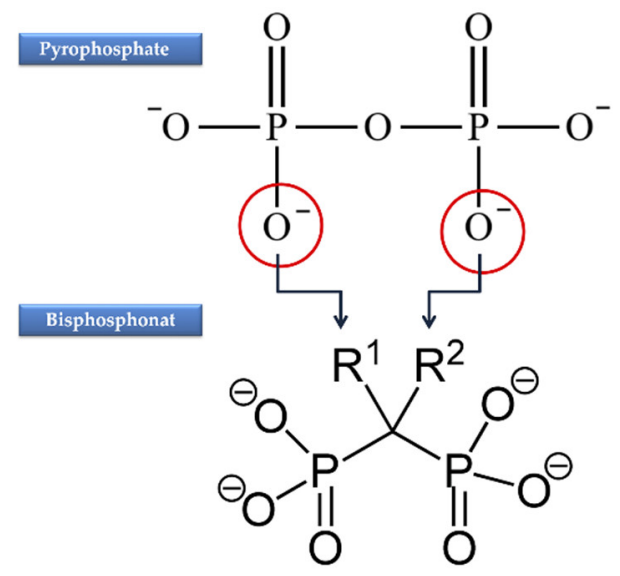

By modifying the first generation of bisphosphonates through adding an amino group into their chemical structure the second generation of bisphosphonates was developed. This group of nitrogen-containing bisphosphonates (N BPs) includes Alendronate, Zolendronate, Ibandronate, Pamidronate and Risedronate (Figure 2.) (6).

The addition of amino groups increased their efficiency and expanded the indications for their use $(1,4,7)$. Some studies indicate that bisphosphonates inhibit tumor development and enhance the effect of cytostatic by synergically affecting the mechanisms of adhesion, proliferation and invasion of tumour cells $(1,7)$. They have been also found to have antiangiogenic effects and immunomodulatory properties (8). Therefore, the bisphosphonates are in clinical use for the treatment of systemic bone diseases and bone metastases. Numerous experimental studies suggest that bisphosphonates could be successfully used in various diseases leading to bone resorption in oral cavity, such as periodontitis, peri-implantitis and periapical lesions $(9-12)$.
Figure 2. Chemical structures of the second generation bisphosphonates.

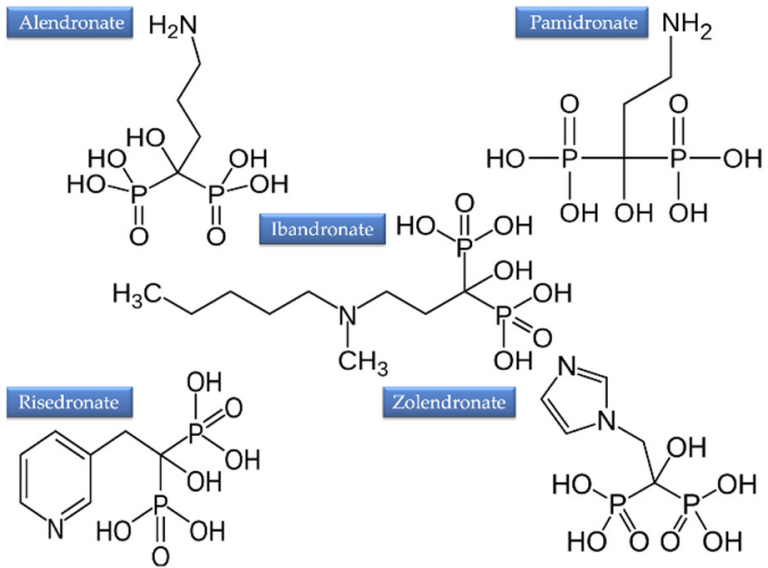

The aim of this study was to review the results of previous studies regarding the potential role of bisphosphonates in the immunomodulation of inflammatory osteoclastogenesis, and the possibility of their application in the treatment of dental diseases which lead to alveolar bone resorption.

\section{THE MECHANISM OF ACTION OF BISPHOSPHONATES}

Reconstruction or remodeling of bone tissue is basically a complex regeneration process that includes both bone resorption and bone synthesis. The important role in the regulation of this process have receptor activator of nuclear factor kappa B (RANK), its ligand (RANKL), osteoprotegerin (OPG) and canonical Wingless (Wnt) pathways (13). Binding of RANKL to RANK, expressed on osteoclast precursors, stimulates their differentiation. Further differentiation into mature osteoclast can be impaired by the binding of a competitive OPG molecule to RANKL and its inactivation. The RANKL/OPG ratio in bone tissue determines the rate of osteclastogenesis and bone resorption $(14,15)$. Other than them, bone metabolism is also affected by numerous paracrine and endocrine regulators. The group of paracrine regulators includes cytokines, prostaglandins and growth factors, while the group of endocrine regulators includes growth hormone, vitamin D, calcitonin, parathyroid hormone, glucocorticoids, androgens, sex and thyroid hormones (16).

The bone is primarily consisted of an organic matrix and crystals of hydroxyapatite. In addition, bone contains water, lipids, non-collagenous proteins and specialized bone tissue cells including osteoblasts, osteocytes, and osteoclasts (17).

The main effect of bisphosphonates is the inhibition of osteoclasts, the cells responsible for bone resorption. Two negatively charged phosphate groups in the structure of nitrogen-containing bisphosphonates contribute to their high affinity to hydroxyapatite enabling their accumulation on the bone surface. While osteoclasts dissolve the organic bone matrix, the accumulated bisphosphonate is being released 
and taken up by the osteoclasts by process of endocytosis (18). Endocytosed bisphosphonates inhibit the major enzyme of mevalonate pathway, farnesylpyrophosphate synthase (FPPS), leading to a decrease in farnesylpyrophosphate (FPP) and geranylgeraniol pyrophosphate (GGPP) thereby preventing the activation of signaling proteins Rac, Ras and Rho and activation of osteoclasts (Figure 3.) (19-21).

Figure 3. Schematic representation of the mechanism of nitrogen bisphosphonates action in osteoclast inhibition.

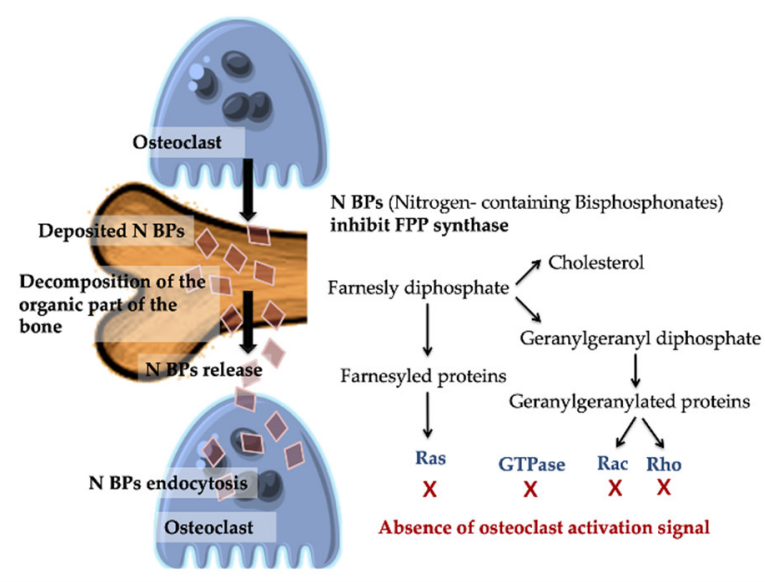

\section{DENTAL IMPLANTS AND BISPHOSPHONATES}

Dental implants are increasingly used in the rehabilitation of the stomatognathic system (22). After the implant is placed, a cascade of molecular and cellular processes take place leading to its osseointegration, i.e. the formation of new bone which is in the direct contact with the surface of the implant. This process is similar to the process of bone fracture healing, and is mostly successful in healthy patients (23). Systemic diseases, such as diabetes mellitus, osteoporosis and malignancies which have an impact on bone metabolism, can impair implant osseointegration leading to the so called "implant loss". In addition, smoking and periodontal disease increase the risk of implant loss $(24,25,26)$.

Treatment of osteoporosis, which involves the use of bisphosphonates is believed to be one of the factors that could jeopardize the osseointegration of the implant. I order to examine that assumption, numerous studies have been conducted with opposing results $(26,27,28)$. A study of Andreas et al. (29) showed that oral intake of low doses of bisphosphonates during the treatment of osteoporosis does not jeopardize implant therapy at all, nor does it lead to the development of possible complications, such as alveolar bone osteonecrosis, peri-implantitis and bone loss. However relevant data are lacking to indicate whether high doses of bisphosphonates and their long-term use can cause such consequences and implant loss (30). Javier et al. (25) reported that bisphosphonates did not reduce the success of implant therapy, but that there was a possibility for the development of complications, and that additional research is needed to estimate individual risk factors for developing osteonecrosis in those patients. In addition to the effects of systemic use of bisphosphonate on implant therapy, their local effect was investigated and it was reported that coating the implant with Zolendronate improves the process of osseointegration (31, 32).

\section{PERIAPICAL LESIONS AND BISPHOSPHONATES}

Periapical lesions are among the most common oral diseases followed by bone resorption. They develop as a consequence of an infected necrotic pulp tissue in the root canal followed by an inflammatory reaction of the surrounding tooth tissue, i.e. apical periodontium. This inflammatory reaction is characterized by an infiltration of immune cells, generation of inflammatory granular tissue, and activation of bone resorption leading to the widening of the apical periodontal space, and ultimately to tooth loss (33). A study conducted on animal model of postmenopausal osteoporosis showed a positive effect of nine weeks Alendronat treatment on periapical lessons. The treatment resulted in smaller periapical lesions, with a slightly enlarged periodontal space, and an inflammatory infiltrate of moderate intensity in which macrophages cells were dominant. However, it has not been shown that Alendronate affected the number of osteoclasts and the ratio of osteoclastogenesis markers (RANKL / OPG), but it did reduce osteocyte apoptosis and the production of cytokine, interleukin (IL)- 6 (12). Similarly to Alendronate, the treatment with Zolendronate also resulted in the reduction of lesions' dimensions, but it did not show any change in the intensity of inflammatory infiltrate. A study of Franca et al. (34) showed that Zolendronate was significantly more efficient in alternating the development of periapical lesions when used prior to their induction then after. In has been shown that Zolendronate compensated for the estrogen deficiency in animal models of postmenopausal osteoporosis, inducing ostoeclast apoptosis and inhibiting their differentiation, thus reducing the number of Tartrate resistant acid phosphatase (TRAP) positive cells and bone resorption (35). Although the positive effect of systematic application of bisphosphonates on the development and the pathogenesis of periapical lesions has been reported, there are no available relevant data on the effects of their local application.

\section{PERIODONTITIS AND BISPHOSPHONATES}

Periodontitis is a multifactorial disease. Persistent gingivitis, caused by subgingival dental plaque, is the key risk factor for the development of periodontitis and the most often is caused by inadequate oral hygiene (36). The infiltration of subgingival dental plaque with Gram-negative bacteria and release of the large amounts of lipopolysaccharides by those bacteria affect and modulate the host immune response by increasing the production of proinflammatory cytokines leading to inflammation of periodontal tissue, bone resorption 
and, if left untreated, ultimately to tooth loss (37). Despite numerous measures for the prevention and treatment of periodontitis, it is still one of the two leading causes of premature tooth loss in addition to caries (38).

Matrix metaloproteinases (MMPs), of which collagenases (MMPs 1,8 and 13) and gelatinases (MMPs 2 and 9), play an important role in the pathogenesis of periodontitis $(39,40)$. N BPs are shown to affect the expression of MMPs, but the effects differ based on the route of N BPs administration $(40,41)$. Seven-day oral administration of Alendronate in the treatment of experimental periodontitis significantly contributed to the reduction of MMP-8 expression, while the treatment with a combination of Alendronate and Doxycycline by gavage led to the slight increase in MMP-8 expression (40). In addition, parenteral administration of Zolendronate showed an increase in the expression of MMP-9 and MMP-13 (41). Alendronate was found to have a beneficial effect on the clinical and radiological findings in the treatment of periodontitis (42-47). The local use of $1 \%$ alendronate gel in combination with platelet-enriched fibrin resulted in a decrease in the depth of the periodontal pockets and an increase in the vertical and horizontal bone levels in the mandibular alveolar bone $(42,43)$. The combination of photodynamic therapy and subcutaneous application of Alendronate also showed good therapeutic effects in the periodontitis treatment with the reduction of alveolar bone loss (44), as well as when applied subgingival by itself (45). Bisphosphonates were also shown to have antibacterial properties towards the biofilm of the dental plaque. In a study of Hiltunen et al (46), Risedronate showed high antibacterial effect on a strain of Aggregatibacter actinomycetemcomitans, a bacteria that is usually found in aggressive forms of periodontal disease. To this day, most studies indicate that the use of bisphosphonates could reduce the progression of alveolar bone loss and tooth luxation and in the end prevent the tooth loss caused by periodontitis.

\section{JAW OSTEONECROSIS AS A SIDE EFFECT OF BISPHOSPHONATE THERAPY}

Osteonecrosis of the alveolar bone or so called "jaw osteonecrosis" was reported as the most severe side effect of bisphosphonates' use $(47,48)$. The exact pathophysiological mechanisms of its development have not been fully explained (49, 50). Although a wide range of positive effects of bisphosphonates has been confirmed, due to the severity of the clinical picture, jaw osteonecrosis presents a great limitation for the expansion of their use $(51,52)$. The prevalence of jaw osteonecrosis was shown to be the highest in the age group of patients between 55-74 years (53). American Association of Oral and Maxillofacial Surgeons (AAOMS) described the criteria for the diagnosis of bisphosphonate related osteonecrosis of the alveolar bone (Table 1.) (54).

Bisphosphonate therapy in patients with bone malignancies showed a higher risk of developing jaw osteonecrosis than in patients with osteoporosis (55). It has not been clarified whether the reason for the more frequent occurrence of jaw osteonecrosis in patients with malignancies is due to the state of general immunosuppression in these patients or due to the length and higher doses used in the treatment of bone metastases (56). The frequency of jaw osteonecrosis in patients with malignancies range from 0.2 to $6.7 \%$, while in patients with other disorders of bone metabolism it ranges from $0 \%$ to $0.4 \%$ (57). The route of bisphosphonates' administration, as well as the length of bisphosphonates' application, could be one of the determining factors in osteonecrosis development. In fact, it was shown that intravenous administration of bisphosphonates increases the risk of developing jaw osteonecrosis, and that the number of registered patients with bisphosphonate related jaw osteonecrosis rose with the increase of the time of intravenous therapy (58). In addition, previously reported research showed that local application of bisphosphonates for a short time period did not result in any side effects, but rather have had a beneficial effect on the healing processes in alveolar bone $(31,32,34,42-44)$.

Table 1. The criteria for the diagnosis of bisphosphonate related osteonecrosis of the alveolar bone according to the Special Ccommittee of American Association of Oral and Maxillofacial Surgeons (50).

\section{Diagnosis criteria of osteonecrosis of the alveolar bone according of the American Association of Oral and Maxillofacial Surgeons special committee}

1. Presence of exposed bone (or bone that can be probed through an intraoral or extraoral fistula) in the maxillofacial region over a period of 8 weeks.

2. Current or previous treatment with antiresorptive (bisphosphonates or denosumab) or anti-angiogenic agents.

3. No history of radiation therapy to the jaw or obvious metastatic disease to the jaw.

Authors have also speculated that bisphosphonates do not cause the jaw osteonecrosis due to their effects on bone metabolism, but due to their other properties (59). Oral surgical interventions were often associated with the occurrence of jaw osteonecrosis due to the exposure of alveolar bone tissue to different strains of oral bacteria (60). In fact, as bisphosphonates deposited in bone tissue bound to bone's hydroxyapatite, they make the surface of the exposed alveolar bone more susceptible to the adhesion of bacteria which could lead to the infection of the bone and possible jaw osteonecrosis (59).

The number of patients in need for bisphosphonate therapy is continuously increasing, which requires additional studies to clarify all positive and negative effects of their use in order to define the prevention and treatment strategy of bisphosphonate related jaw osteonecrosis. 


\section{CONCLUSION}

In conclusion, bisphosphonates are considered the most effective drug for the treatment of disorders associated with bone resorption. The indications for their use are still limited due to the occurrence of bisphosphonate related jaw osteonecrosis, even though research have shown that they have a beneficial effects on the most common diseases of alveolar bone such as peri-implantitis, periapical lesions and periodontitis. Local application of bisphosphonates to prevent and reduce alveolar bone resorption could be the most optimal method of administration. Especially, based on the results of previous experimental studies, we can conclude that such application would eliminate the potential side effects related to their systemic application. The results of experimental studies encourage thinking about expanding the indications for the use of bisphosphonates in dentistry, but also emphasize the need for further research. The exact dose, method and duration of their application in the treatment of peri-implantitis, periapical lesions, and periodontitis, remains poorly defined and should be the subject of future research.

\section{ACKNOWLEDGMENTS}

Authors research work was supported by the Ministry of Education, Science and Technological Development of the Republic of Serbia (Grant no. 175071).

\section{CONFLICT OF INTEREST}

The authors declare no financial or commercial conflict of interest.

\section{REFERENCES}

1. Kuźnik A, Październiok-Holewa A, Jewula P, Kuźnik N. Bisphosphonates-much more than only drugs for bone diseases. Eur J Pharmacol. 2020;866:172773

2. Giger EV, Castagner B, Leroux JC. Biomedical applications of bisphosphonates. $\mathrm{J}$ Control Release 2013;167:175-188.

3. Jung J, Park JS, Righesso L, et al. Effects of an oral bisphosphonate and three intravenous bisphosphonates on several cell types in vitro. Clin Oral Investig. 2018;22:2527-2534.

4. Kos M. Incidence and risk predictors for osteonecrosis of the jaw in cancer patients treated with intravenous bisphosphonates. Arch Med Sci. 2015;11:319-324.

5. Di Fede O, Panzarella V, Mauceri R, et al. The Dental Management of Patients at Risk of Medication-Related Osteonecrosis of the Jaw: New Paradigm of Primary Prevention. Biomed Res Int. 2018;2018:2684924. Published 2018 Sep 16.

6. Kates SL, Ackert-Bicknell CL. How do bisphosphonates affect fracture healing?. Injury. 2016;47 Suppl 1:S65-S68.
7. Giger EV, Castagner B, Leroux JC. Biomedical applications of bisphosphonates. J Control Release 2013; 167: 175-188.

8. Savino S, Toscano A, Purgatorio R, et al. Novel bisphosphonates with antiresorptive effect in bone mineralization and osteoclastogenesis. Eur J Med Chem. 2018;158:184-200.

9. De Colli M, Tortorella $\mathrm{P}$, Agamennone $\mathrm{M}$, et al. Bisphosfonate matrix metalloproteinase inhibitors for the treatment of periodontitis: An in vitro study. Int J Mol Med. 2018;42:651-657.

10. Akram Z, Abduljabbar T, Kellesarian SV, Abu Hassan MI, Javed F, Vohra F. Efficacy of bisphosphonate as an adjunct to nonsurgical periodontal therapy in the management of periodontal disease: a systematic review. $\mathrm{Br}$ J Clin Pharmacol. 2017;83:444-454.

11. Wayama MT, Yoshimura H, Ohba S, et al. Diminished Progression of Periapical Lesions with Zoledronic Acid in Ovariectomized Rats. J Endod. 2015;41:2002-2007.

12. Silva RAB, Sousa-Pereira AP, Lucisano MP, et al. Alendronate inhibits osteocyte apoptosis and inflammation via IL-6, inhibiting bone resorption in periapical lesions of ovariectomized rats. Int Endod J. 2020;53:8496.

13. Compston JE, McClung MR, Leslie WD. Osteoporosis. Lancet. 2019;393:364-376.

14. Weitzmann MN. Bone and the Immune System. Toxicol Pathol. 2017;45:911-924.

15. Tobeiha M, Moghadasian MH, Amin N, Jafarnejad S. RANKL/RANK/OPG Pathway: A Mechanism Involved in Exercise-Induced Bone Remodeling. Biomed Res Int. 2020;2020:6910312. Published 2020 Feb 19.

16. Kenkre JS, Bassett J. The bone remodelling cycle. Ann Clin Biochem. 2018;55(3):308-327.

17. Holstein SA. A patent review of bisphosphonates in treating bone disease. Expert Opin Ther Pat. 2019;29:315-325.

18. Yu Z, Surface LE, Park CY, et al. Identification of a transporter complex responsible for the cytosolic entry of nitrogen-containing bisphosphonates. Elife. 2018; 7:e36620. Published 2018 May 10.

19. Cremers S, Drake MT, Ebetino FH, Bilezikian JP, Russell RGG. Pharmacology of bisphosphonates. Br J Clin Pharmacol. 2019;85:1052-1062.

20. Dayanand P, Sandhyavenu H, Dayanand S, Martinez J, Rangaswami J. Role of Bisphosphonates in Vascular calcification and Bone Metabolism: A Clinical Summary. Curr Cardiol Rev. 2018;14:192-199.

21. Zameer S, Najmi AK, Vohora D, Akhtar M. Bisphosphonates: Future perspective for neurological disorders. Pharmacol Rep. 2018;70:900-907.

22. Noronha Oliveira M, Schunemann WVH, Mathew MT, et al. Can degradation products released from dental implants affect peri-implant tissues?. J Periodontal Res. 2018;53:1-11. 
23. Pellegrini G, Francetti L, Barbaro B, Del Fabbro M. Novel surfaces and osseointegration in implant dentistry. J Investig Clin Dent. 2018;9:e12349.

24. Turri A, Rossetti PH, Canullo L, et al. Prevalence of peri-implantitis in medically compromised patients and smokers: a systematic review. Int J Oral Maxillofac Implants. 2016;31:111-118.

25. Meyle J, Casado P, Fourmousis I, Kumar P, Quirynen M, Salvi GE. General genetic and acquired risk factors, and prevalence of peri-implant diseases - Consensus report of working group 1. Int Dent J. 2019;69 Suppl 2:36.

26. French D, Grandin HM, Ofec R. Retrospective cohort study of 4,591 dental implants: Analysis of risk indicators for bone loss and prevalence of peri-implant mucositis and peri-implantitis. $J$ Periodontol. 2019;90:691-700.

27. Ata-Ali J, Ata-Ali F, Peñarrocha-Oltra D, GalindoMoreno P. What is the impact of bisphosphonate therapy upon dental implant survival? A systematic review and meta-analysis. Clin Oral Implants Res. 2016;27:e38-e46

28. de-Freitas NR, Lima LB, de-Moura MB, VelosoGuedes CC, Simamoto-Júnior PC, de-Magalhães D. Bisphosphonate treatment and dental implants: A systematic review. Med Oral Patol Oral Cir Bucal. 2016;21:e644-e651. Published 2016 Sep 1.

29. Stavropoulos A, Bertl K, Pietschmann P, Pandis N, Schiødt M, Klinge B. The effect of antiresorptive drugs on implant therapy: Systematic review and meta-analysis. Clin Oral Implants Res. 2018;29 Suppl 18:54-92.

30. Khoury F, Hidajat H. Extensive Autogenous Bone Augmentation and Implantation in Patients Under Bisphosphonate Treatment: A 15-Case Series. Int J Periodontics Restorative Dent. 2016;36:9-18

31. Kellesarian SV, Subhi ALHarthi S, Saleh Binshabaib M, Javed F. Effect of local zoledronate delivery on osseointegration: a systematic review of preclinical studies. Acta Odontol Scand. 2017;75:530-541.

32. He Y, Bao W, Wu XD, Huang W, Chen H, Li Z. Effects of Systemic or Local Administration of Zoledronate on Implant Osseointegration: A Preclinical Meta-Analysis. Biomed Res Int. 2019;2019:9541485. Published 2019 Sep 22.

33. Liapatas S, Nakou M, Rontogianni D. Inflammatory infiltrate of chronic periradicular lesions: an immunohistochemical study. Int Endod J. 2003.

34. França TRT, Ramos-Perez FMM, Pontual ADA, Castro JFL, Bonan PRF, Perez DEDC. Effects of Zoledronic Acid in Experimental Periapical Lesions in Rats: An Imaging and Histological Analysis. Braz Dent $J$. 2017;28:566-572.

35. Wayama MT, Yoshimura H, Ohba S, et al. Diminished Progression of Periapical Lesions with Zoledronic Acid in Ovariectomized Rats. J Endod. 2015;41:2002-2007.

36. Lertpimonchai A, Rattanasiri S, Arj-Ong Vallibhakara S, Attia J, Thakkinstian A. The association between oral hygiene and periodontitis: a systematic review and meta-analysis. Int Dent J. 2017;67:332-343.
37. Martinho FC, Leite FR, Nóbrega LM, et al. Comparison of Fusobacterium nucleatum and Porphyromonas gingivalis Lipopolysaccharides Clinically Isolated from Root Canal Infection in the Induction of Pro-Inflammatory Cytokines Secretion. Braz Dent J. 2016;27:202207.

38. Frencken JE, Sharma P, Stenhouse L, Green D, Laverty D, Dietrich T. Global epidemiology of dental caries and severe periodontitis - a comprehensive review. J Clin Periodontol. 2017;44 Suppl 18:S94-S105.

39. De Colli M, Tortorella P, Agamennone $\mathrm{M}$, et al. Bisphosfonate matrix metalloproteinase inhibitors for the treatment of periodontitis: An in vitro study. Int J Mol Med. 2018;42:651-657.

40. Buduneli E, Vardar-Şengül S, Buduneli N, Atilla G, Wahlgren J, Sorsa T. Matrix Metalloproteinases, Tissue Inhibitor of Matrix Metalloproteinase-1, and Laminin5 2 Chain Immunolocalization in Gingival Tissue of Endotoxin-Induced Periodontitis in Rats: Effects of Low-Dose Doxycycline and Alendronate. J Periodontol. 2007;78:127-134.

41. Soundia A, Hadaya D, Esfandi N, et al. Zoledronate Impairs Socket Healing after Extraction of Teeth with Experimental Periodontitis. J Dent Res. 2018;97:312-320.

42. Kanoriya D, Pradeep AR, Singhal S, Garg V, Guruprasad CN. Synergistic Approach Using Platelet-Rich Fibrin and 1\% Alendronate for Intrabony Defect Treatment in Chronic Periodontitis: A Randomized Clinical Trial. J Periodontol. 2016;87:1427-1435.

43. Kanoriya D, Pradeep AR, Garg V, Singhal S. Mandibular Degree II Furcation Defects Treatment With Platelet-Rich Fibrin and 1\% Alendronate Gel Combination: A Randomized Controlled Clinical Trial. J Periodontol. 2017;88:250-258.

44. Camacho-Alonso F, Davia-Peña RS, Vilaplana-Vivo C, Tudela-Mulero MR, Merino JJ, Martínez-Beneyto Y. Synergistic effect of photodynamic therapy and alendronate on alveolar bone loss in rats with ligature-induced periodontitis. J Periodontal Res. 2018;53:306314.

45. Sharma A, Raman A, Pradeep AR. Role of 1\% alendronate gel as adjunct to mechanical therapy in the treatment of chronic periodontitis among smokers. $J$ Appl Oral Sci. 2017;25:243-249.

46. Hiltunen AK, Skogman ME, Rosenqvist K, et al. Bioactive glass combined with bisphosphonates provides protection against biofilms formed by the periodontal pathogen Aggregatibacter actinomycetemcomitans. Int J Pharm. 2016;501:211-220.

47. Kuroshima S, Sasaki M, Sawase T. Medication-related osteonecrosis of the jaw: A literature review. J oral Biosci. 2019;61:99-104. * Beth-Tasdogan NH, Mayer $\mathrm{B}$, Hussein $\mathrm{H}$, Zolk O. Interventions for managing medication-related osteonecrosis of the jaw. Cochrane Database Syst Rev. 2017;10:CD012432. Published 2017 Oct 6.

48. Khan A, Morrison A, Cheung A, Hashem W, Compston J. Osteonecrosis of the jaw (ONJ): diagnosis and management in 2015. Osteoporos Int. 2016;27:853-859. 
49. Otto S, Pautke C, Van den Wyngaert T, Niepel D, Schiødt M. Medication-related osteonecrosis of the jaw: Prevention, diagnosis and management in patients with cancer and bone metastases. Cancer Treat Rev. 2018;69:177-187.

50. Holtmann H, Lommen J, Kübler NR, et al. Pathogenesis of medication-related osteonecrosis of the jaw: a comparative study of in vivo and in vitro trials. $J$ Int Med Res. 2018;46:4277-4296.

51. Nicolatou-Galitis O, Kouri M, Papadopoulou E, et al. Osteonecrosis of the jaw related to non-antiresorptive medications: a systematic review. Support Care Cancer. 2019;27:383-394.

52. Fassio A, Bertoldo F, Idolazzi L, Viapiana O, Rossini M, Gatti D. Drug-induced osteonecrosis of the jaw: the state of the art. Reumatismo. 2017;69:9-15.

53. Mânea HC, Urechescu HC, Balica NC, et al. Bisphosphonates-induced osteonecrosis of the jaw - epidemiological, clinical and histopathological aspects. Rom J Morphol Embryol. 2018;59:825-831.

54. Ruggiero SL. Diagnosis and Staging of Medication-Related Osteonecrosis of the Jaw. Oral Maxillofac Surg Clin North Am. 2015;27:479-487.
55. Ruggiero S, Dodson T, Fantasia J, et al. American Association of Oral and Maxillofacial Surgeons paper on medication-related osteonecrosis of the jaw-2014 update. J Oral Maxillofac Surg 2014;72:1938-56.

56. Dodson TB. Risk Factors.Oral Maxillofac Surg Clin North Am. 2015; 27: 509-516.

57. Di Fede O, Panzarella V, Mauceri R, et al. The Dental Management of Patients at Risk of Medication-Related Osteonecrosis of the Jaw: New Paradigm of Primary Prevention. Biomed Res Int. 2018;2018:2684924. Published 2018 Sep 16.

58. Mücke T, Krestan CR, Mitchell DA, Kirschke JS, Wutzl A. Bisphosphonate and Medication-Related Osteonecrosis of the Jaw: A Review. Semin Musculoskelet Radiol. 2016;20:305-314.

59. Kos M, Junka A, Smutnicka D, Bartoszewicz M, Kurzynowski T, Gluza K. Pamidronate enhances bacterial adhesion to bone hydroxyapatite. Another puzzle in the pathology of bisphosphonate-related osteonecrosis of the jaw? J Oral Maxillofac Surg. 2013;71:1010-6.

60. Kos M. Incidence and risk predictors for osteonecrosis of the jaw in cancer patients treated with intravenous bisphosphonates. Arch Med Sci. 2015;11:319-324. 